\title{
PENCARIAN CONTENT PORTAL WEB BERITA DENGAN TEKNIK SINDIKASI BERBASIS AJAX-SOAP WEB SERVICE
}

\author{
Bernard Renaldy Suteja \\ Teknik Informatika, Fakultas Teknologi Informasi UK. Maranatha \\ Surya Sumantri 65 Bandung \\ bernard.rs@it.maranatha.edu
}

\begin{abstract}
Much of the latest information is spread through web news portals and has the difficulty of finding a desired content. It takes time to browse through many portals and identify the desired content. To track any updates from a web portal can be used Really Simple Syndication (RSS) technique. By using the technique of syndication, it can be made a search engine that allows to bring the desired content from the number of news web portals. Implementation of AJAX-SOAP web service will make the resulting search engine responsive and have good interoperability.
\end{abstract}

Keywords: syndication, rss, soap, news web portals

\section{Latar Belakang Masalah}

Era teknologi internet telah melahirkan begitu banyak manfaat termasuk terkait dengan pemberitaan. Portal berita adalah wujud nyata dari manfaat teknologi internet untuk pemberitaan. Kegiatan jurnalistik sangat dimudahkan dengan adanya portal berita. Kegiatan repotase dan distribusi informasi dapat dilakukan dari mana saja dan kapan saja.

Dilihat dari sejarahnya portal berita yang ada di Indonesia dimulai tahun 1994 diawali oleh Republika, yang dapat diakses melalui alamat http://republika.co.id [3]. Hingga saat ini menurut Menkominfo saat ini, 2018, di Indonesia terdapat 43 ribu portal berita namun baru 100 portal berita yang terverifikasi oleh Dewan Pers [2]. Dengan masih banyaknya portal berita yang belum terverifikasi tersebut maka memiliki potensi dalam penyebaran berita yang tidak benar (hoax).

Disisi pengguna atau pencari berita proses mencari atau mendapatkan informasi berita juga bisa merepotkan. Sudah menjadi hal yang sangat biasa dalam mencari informasi berita, pengguna akan melakukan penjelajahan portal berita lebih dari satu. Hal ini terjadi karena kecepatan repotase dalam merekam berita yang terjadi berbeda-beda antara satu portal berita dengan yang lainnya. Untuk tujuan mempermudah dalam pencarian content hingga untuk analisa pemberitaan maka diperlukan suatu upaya menghadirkan informasi yang komprehensif dari semua portal berita yang ada secara cepat.

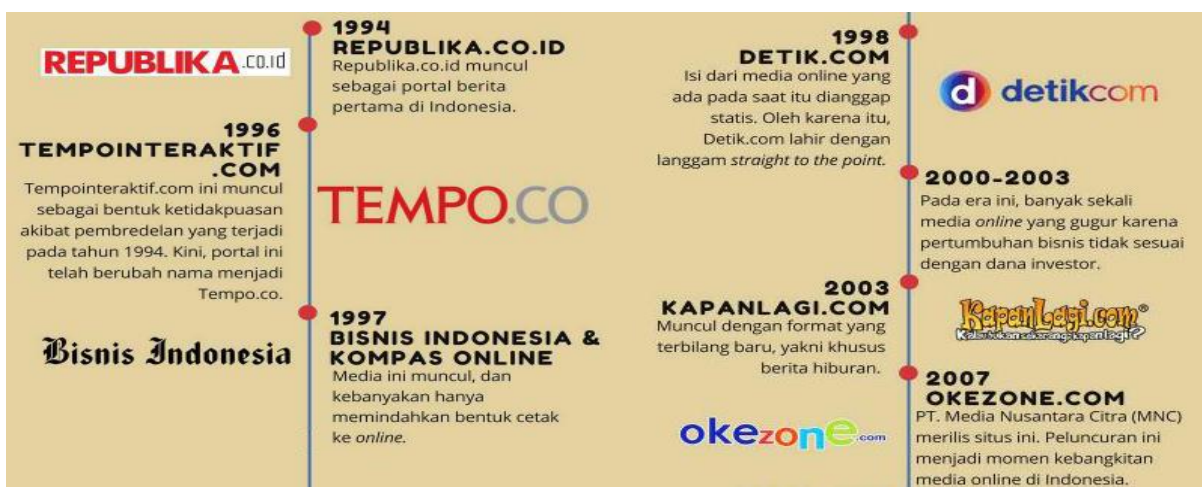

Gambar 1. Sejarah Portal Berita di Indonesia [3] 


\section{Kajian Pustaka}

\subsection{XML}

XML (eXtensible Markup Language) dimanfaatkan untuk representasi data dalam berbagai aplikasi web. Berbeda dengan HyperText Markup Language (HTML) yang menampilkan data secara tidak terstruktur (karena bertujuan hanya untuk menampilkan secara menarik), XML mampu menampilkan data dalam format terstruktur dan mudah dipahami oleh mesin ataupun manusia (machine-usable dan human-readable) [1].

XML dibangun untuk memudahkan dalam proses pengolahan ataupun kombinasi (pertukaran) terhadap data. Sehingga dokumen XML dapat digunakan untuk beberapa kepentingan sekaligus, termasuk didalamnya dapat berbagi data dokumen dengan user lainnya dari bermacammacam aplikasi.

XML bermanfaat untuk pertukaran data khususnya melalui internet, sehingga memungkinkan untuk perbedaan platform saling terintegrasi. Hal sangat dimungkinkan karena XML menititik-beratkan pada struktur, extensible, dan aturan penulisan sintaks yang kuat. Struktur XML secara umum diawali dengan adanya prolog yang berisi deklarasi bahwa ini adalah dokumen XML dan menampilkan nomor versinya, yaitu sebagai berikut: $<$ ?xml version='1.0'? $>$, dilanjutkan dengan elemen-elemen dokumen, serta bagian yang terakhir adanya epilog, yaitu berisikan komentar dan atau white space [1].

\subsection{Really Simple Syndication (RSS)}

RSS merupakan teknik sindikasi untuk mendapatkan pembaharuan informasi dari sebuah situs web berbasis XML [6]. Wujudnya dapat berupa informasi rangkuman terkini dari sebuah web site secara keseluruhan. Sehingga melalui RSS, informasi web dapat secara cepat diketahui tanpa harus mengunjungi situs web secara langsung. Namun demikian perlu diperhatikan informasi yang dihadirkan sangat singkat (berupa rangkuman).

RSS mengarah kebeberapa protokol diantaranya Rich Site Summary (RSS 0.91), RDF Site Summary (RSS 0.9 dan 1.0) dan Really Simple Syndication (RSS 2.0). RSS merupakan dokumen XML dengan suatu ketentuan tag. Sampai saat ini tidak ada standar baku untuk RSS, hanya RSS 0.9 dan 1.0 dengan pendekatan W3C standar Resource Description Framework (RDF) [7].

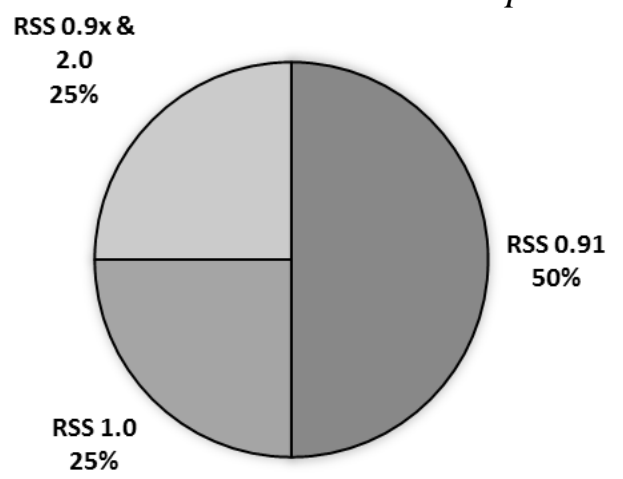

Gambar 2. RSS Menurut W3School

Kebanyakan situs web yang memanfaatkan adalah situs web berita, weblog, web forum dikusi, web komunitas atau web site yang kontennya terkait dengan pemberitaan atau informasi acara/kejadian. Penggunaan RSS turut membantu distribusi informasi secara cepat dan tidak banyak memakan bandwith internet. Pengguna akan mendapat semua informasi dari beberapa situs sekaligus tanpa perlu mengunjunginya satu per-satu. Beberapa contoh situs yang mengimplementasikan RSS adalah sebagai berikut [6] :

"detik" dengan URL "http://rss.detik.com"

"antara" dengan URL "http://www.antaranews.com/rss/terkini"

"voaid" dengan URL "https://www.voaindonesia.com/api/zmgqoemoi"

"sindo" dengan URL "https://www.sindonews.com/feed" 
"liputan6" dengan URL "http://www.liputan6.com/rss"

"tribun" dengan URL "http://www.tribunnews.com/rss"

"metrotv" dengan URL "http://www.metrotvnews.com/feed"

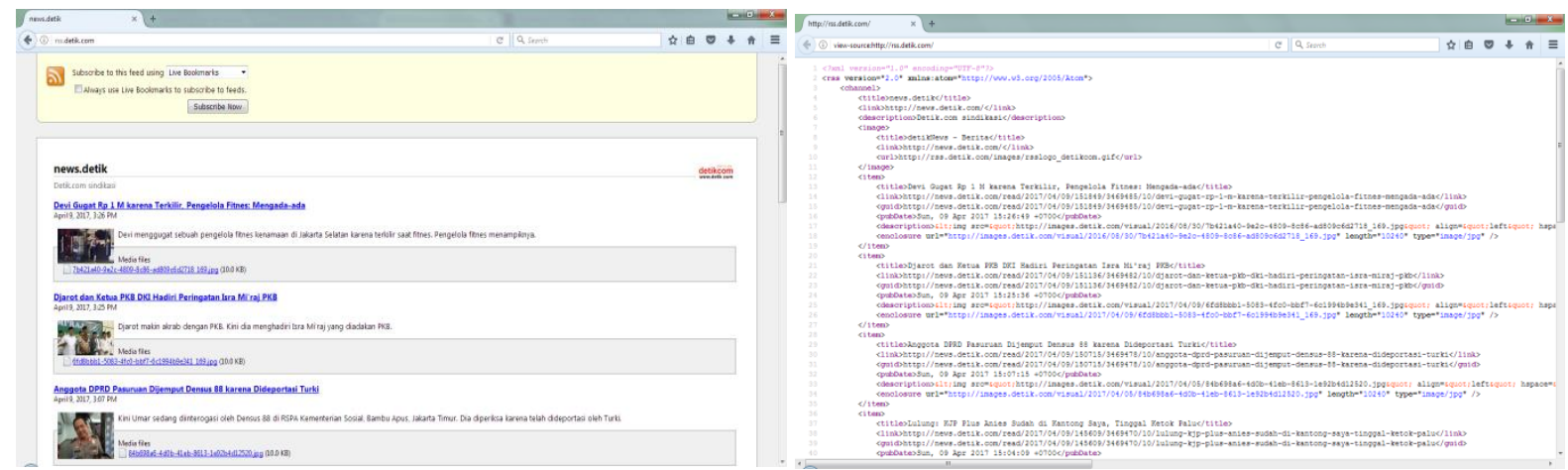

Gambar 3. Tampilan RSS dan RSS-XML dari Portal detik.com

\subsection{Web Service}

Pemanfaatan basis data ternyata juga menimbulkan suatu permasalahan baru, yaitu memiliki ketergantungan pada platform baik sistem operasi, basis data ataupun aplikasi web yang akan dikembangkan. Pertukaran data melalui web merupakan tujuan utama untuk mengkolaborasi datadata yang tersebar diweb sehingga dapat digunakan untuk menghasilkan informasi yang tepat. Sehingga dalam konteks ini sudah seharusnya pertukaran data pada web tidak lagi memandang platofrm dan sudah seharusnya multiplatform.

Proses perukaran data diwakilkan dalam bentuk metode-metode yang dapat diakses tanpa memperhatikan platform dan lebih mengedepankan interoperabilitas interaksi (transaksi) disebut dengan web service. Web service dikembangkan dengan pendekatan SOA (Service Oriented Architecture), untuk memenuhi kebutuhan dan kualitas dari pembangunan aplikasi web. Web service dapat diimplementasikan dengan SOAP (Simple Object Access Protocol) atau REST (Representational State Transfer) [6]. Walaupun memiliki kesamaan dalam pertukaran data dengan berkomunikasi melalui web service, namun tetap memiliki beberapa hal yang berbeda (Tabel 1).

Tabel 1. Perbedaan SOAP dan REST [4]

Uraian

\section{Protokol komunikasi \\ Penggunaan bandwidth}

\begin{tabular}{|l|}
\hline Tren penggunaan \\
\hline \\
\hline Aturan penulisan \\
\hline
\end{tabular}

Format respon

Attachment file

Sifat web servis pada umumnya
SOAP HTTP, HTTPS, SMTP, FTP

Dalam jumlah request yang banyak, relatif boros bandwidth. Hal ini karena banyaknya markup dalam penulisan format XML

Banyak mulai beralih ke REST, meski masih tetap ada yang mempertahankan, misalnya untuk integrasi aplikasi ke sistem legasi pada sebuah perusahaan.

Ketat, mengikuti spesifikasi XML (SOAP v1.2)

XML dengan spesifikasi SOAP. Agak sulit untuk membaca langsung dan memahaminya.

Bisa (karena dapat mengembalikan respon dalam format binary)

Tertutup, lebih ditujukan untuk vendor atau perusahaan tertent

\section{REST}

\section{HTTP, HTTPS}

Relatif hemat bandwidth, karena markupmarkup ekstra seperti pada XML tidak dipakai

Mulai populer, banyak dipakai oleh penyedia web servis terkemuka, seperti twitter, yahoo!, flickr,bloglines, technorati, google, amazon, eBay, dan sebagainya

Tidak ada spesifikasi khusus

XML, JSON, atau format plain teks lainnya. Hal ini memudahkan penerima respon membaca dan memahaminya. Tidak bisa

\section{Terbuka, bisa diakses siapa saja (web} API) 


\begin{tabular}{|l|l|l|}
\hline Caching web & Relatif sulit & Mudah, karena menggunakan URI \\
\hline $\begin{array}{l}\text { Penggunaan } \\
\text { standar }\end{array}$ & $\begin{array}{l}\text { Standar lama (XML, HTTP) dan baru } \\
\text { (SOAP) digunakan bersamaan }\end{array}$ & $\begin{array}{l}\text { Standar yang sudah ada, seperti XML } \\
\text { dan HTTP }\end{array}$ \\
\hline $\begin{array}{l}\text { Tool } \\
\text { pengembangan }\end{array}$ & $\begin{array}{l}\text { Banyak, baik komersial maupun } \\
\text { opensource }\end{array}$ & Beberapa, karena tidak begitu dibutuhkan \\
\hline Tool manajemen & Perlu, bahkan kadang harganya mahal & $\begin{array}{l}\text { Menggunakan tool yang sudah ada pada } \\
\text { sistem jaringan }\end{array}$ \\
\hline Ekstensibel & $\begin{array}{l}\text { Bisa, banyak ekstensi termasuk standar } \\
\text { WS }\end{array}$ & Relatif tidak ekstensibel \\
\hline $\begin{array}{l}\text { Kemudahan } \\
\text { implementasi }\end{array}$ & $\begin{array}{l}\text { Mudah jika sudah memiliki lingkungan } \\
\text { berbasis SOAP }\end{array}$ & Mudah \\
\hline
\end{tabular}

\subsection{Asynchronous Javascript and XML (AJAX)}

AJAX mulai dilirik oleh para web desainer dan web programmer karena dengan adanya AJAX, akses data ke server yang dikirim melalui client via web dapat lebih cepat dari pada mekanisme biasa. Hal ini dikarenakan AJAX tidak perlu melakukan proses loading page (refresh page) atau pindah ke page yang lain. AJAX dapat diintegrasikan dengan server side programming seperti PHP, ASP, JSP dan sebagainya.

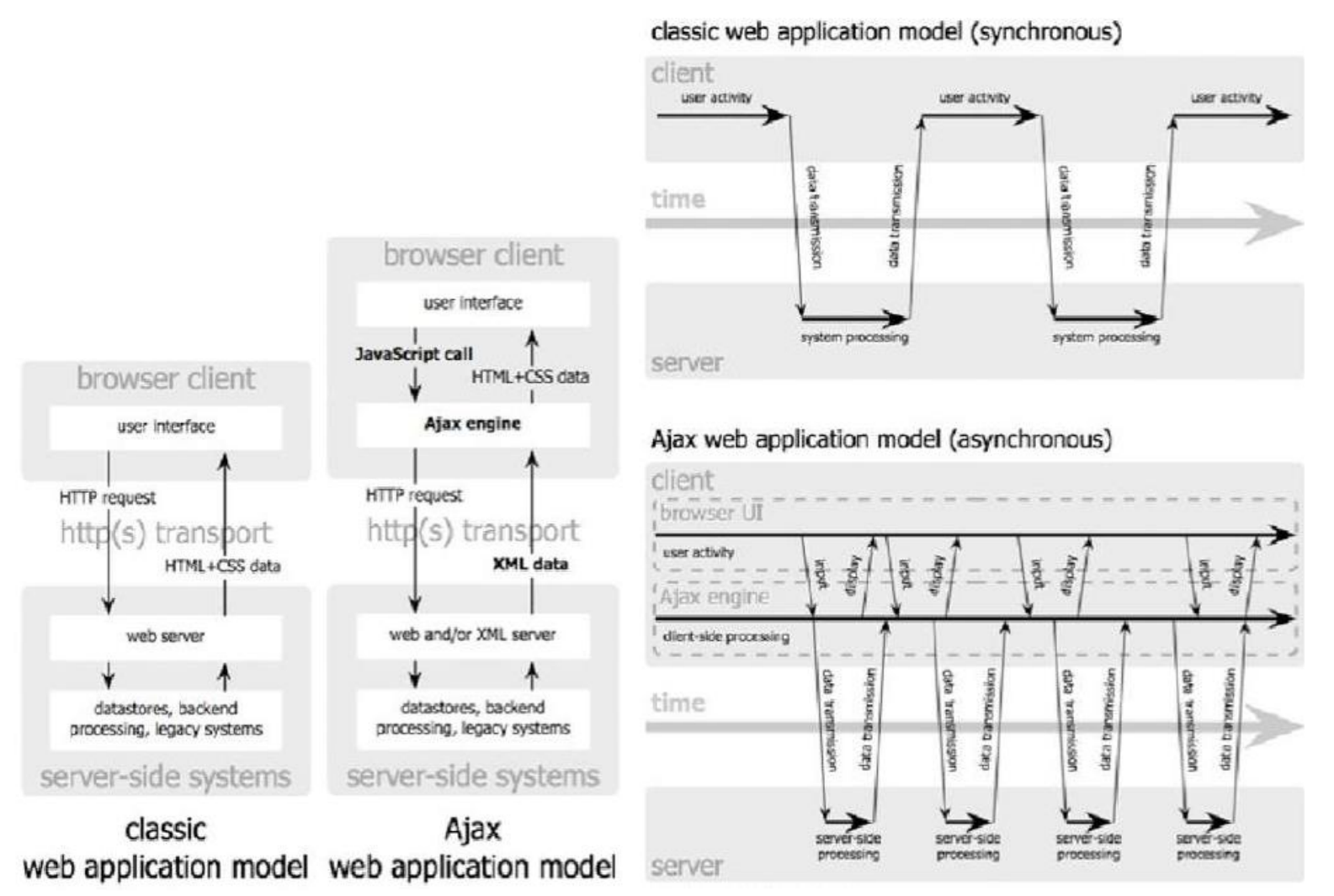

Gambar 4. Perbandingan Mekanisme Proses Model Klasik (Non AJAX) dan AJAX [5]

\section{Metode Perancangan}

Metode yang digunakan dalam pencarian content portal web berita dilakukan dengan melakukan sindikasi portal web berita dengan mengimplementasikan web service SOAP dan mengembangkan client interface untuk pencariannya dengan mengimplementasikan AJAX, seperti Gambar 4. Dalam penelitian ini portal berita yang digunakan ada 7, yaitu : detik, antara, voaindonesia, sindo, liputan6, tribun, dan metrotv. 


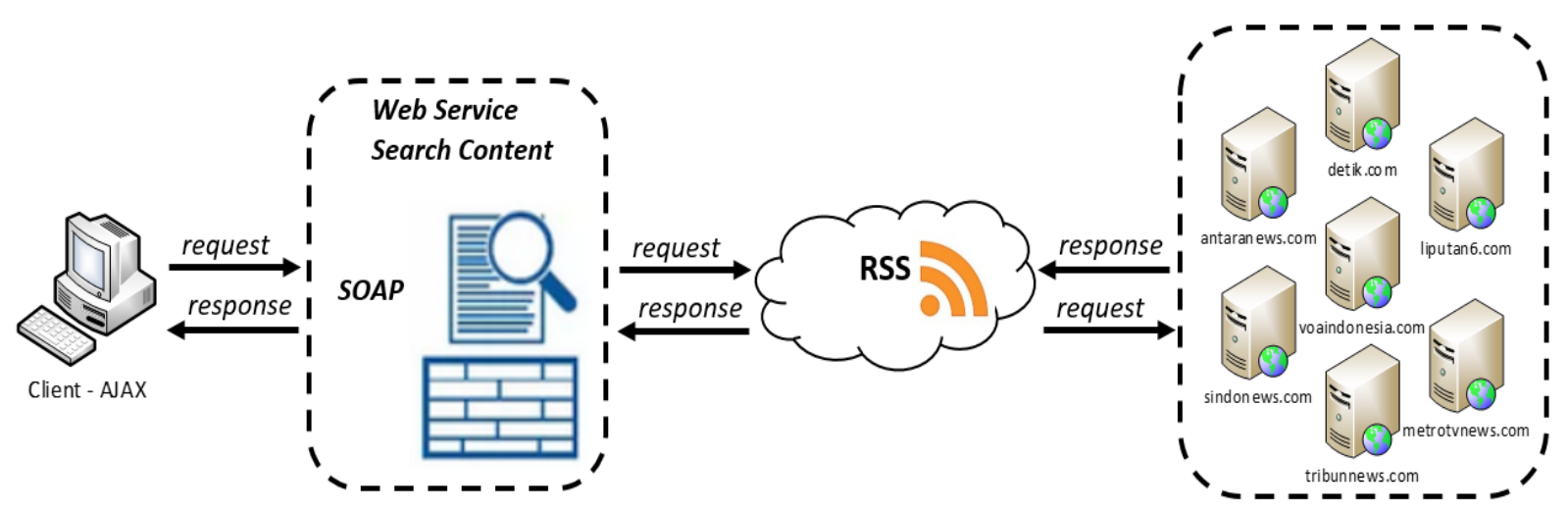

Gambar 5. Arsitektur Pencarian Content Pada Portal Berita dengan Sindikasi

\subsection{Pembuatan Web Service-SOAP}

Perancangan Web Service-SOAP yang akan digunakan untuk mengolah RSS dilakukan dengan urutan sebagai berikut :
a) memanggil library NuSOAP
b) membuat object soap_server
c) konfigurasi WSDL
d) registrasi service RSSSearch
e) aktivasi service

Pada Gambar 6 adalah service RSSSearch yang digunakan pada web service-SOAP pada sisi server dengan menggunakan PHP. Implementasi dari service RSSSearch ini akan dihasilkan Web Services Description Language (WSDL) seperti gambar 7.

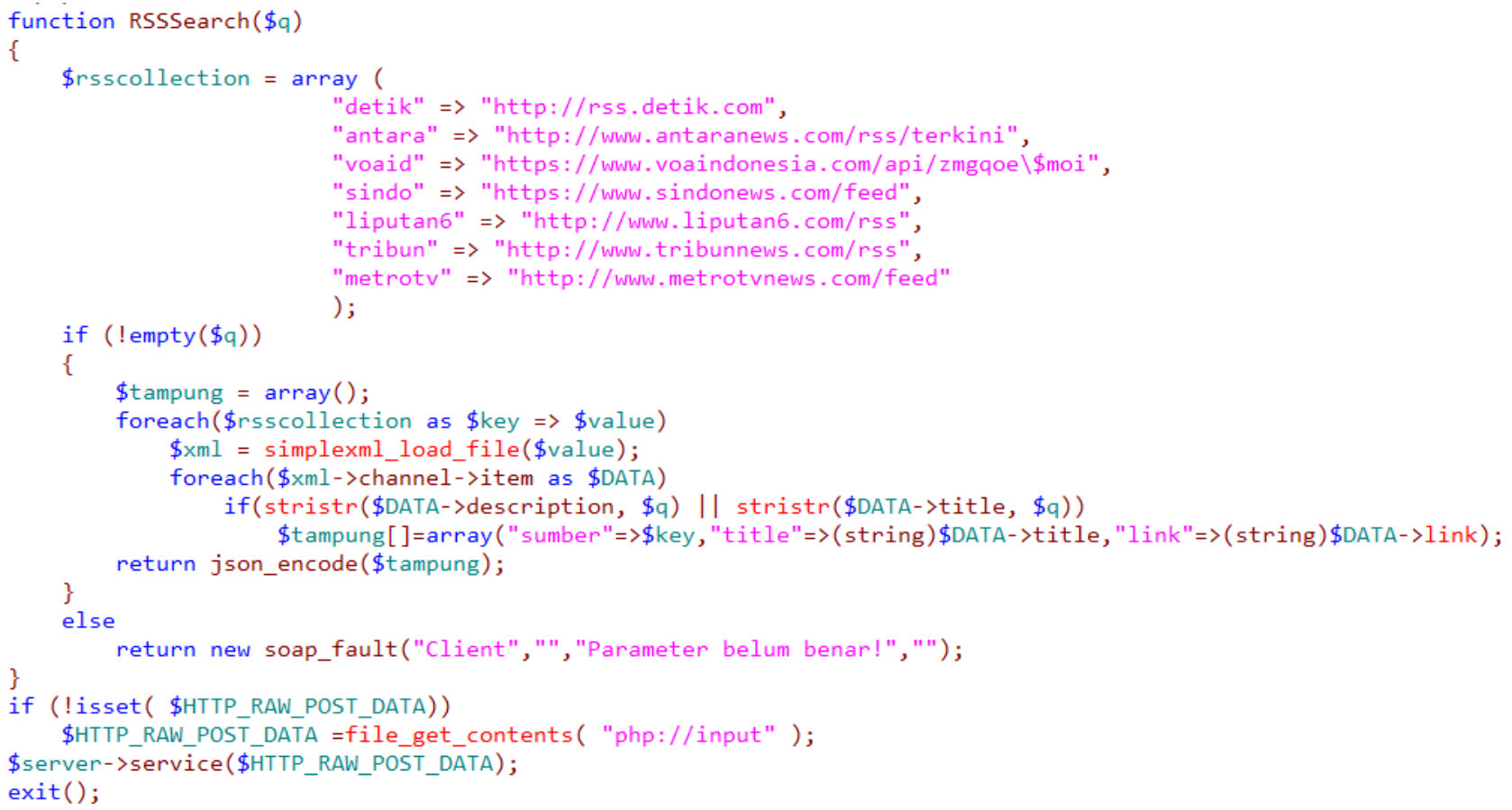

Gambar 6. Method RSSSearch 

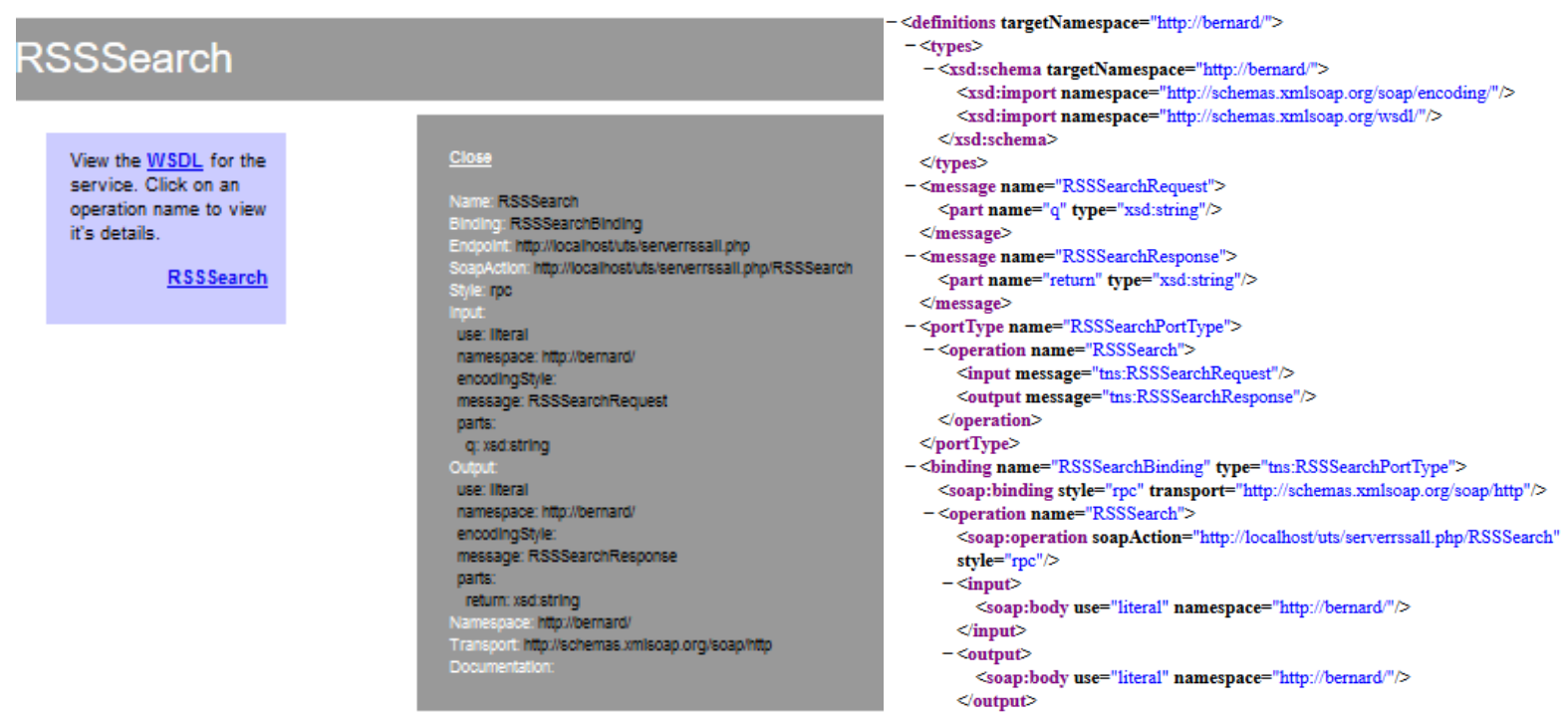

Gambar 7. Service RSSSearch

\subsection{Pemanggilan Service RSSSearch}

Pada bagian client yang akan berkomunikasi dengan web service secara pendekatan SOA dapat dilakukan dengan urutan sebagai berikut :

1) memanggil library NuSOAP

2) membuat object nusoap_client

3) memanggil service RSSSearch

Tugas dari client adalam pemanggilan service dan menerima response dari komunikasi web service SOAP pada sisi server. Parameter yang ada pada service diperoleh dari client. Pada gambar 8 merupakan penggalan program pemanggilan service oleh client.

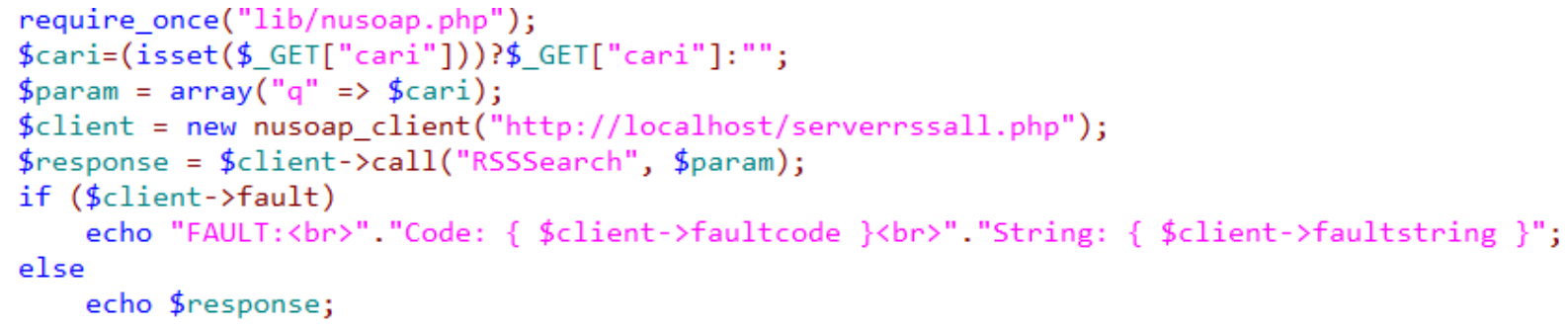

Gambar 8. Pemanggilan Service RSSSearch

\subsection{Implementasi AJAX pada sisi Client Interface}

Langkah awal dalam mengimplementasikan AJAX untuk interaksi pada client interface adalah dengan memanfaatkan sebuah object XMLHttpRequest yang tersedia pada setiap browser client. XMLHttpRequest memiliki metode dan properti yang digunakan untuk melakukan request dan mengangani response.

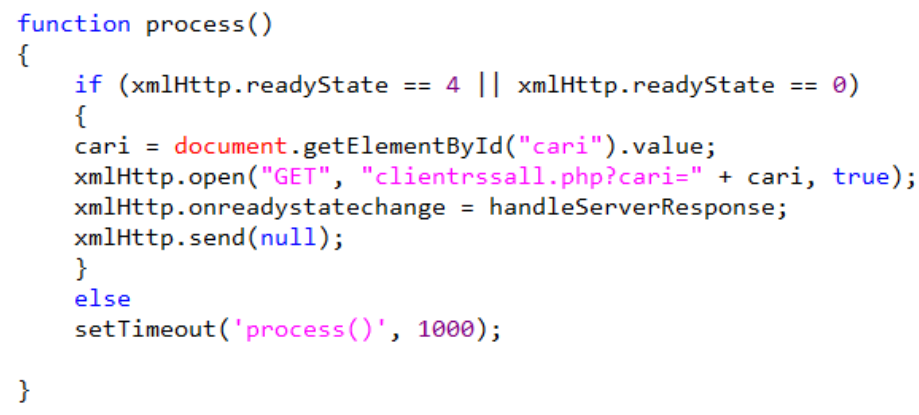




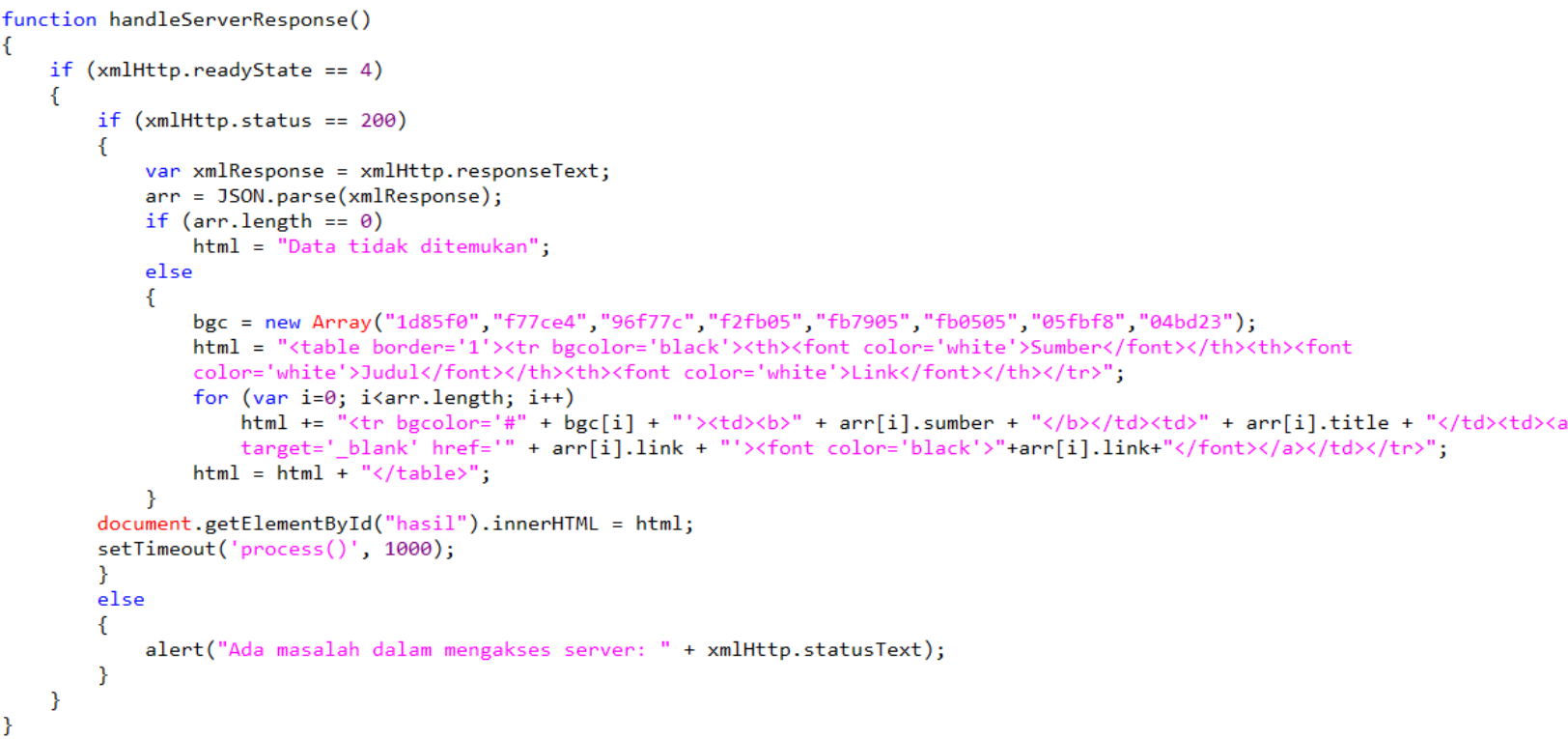

\section{Gambar 9. Implementasi Metode dan Properti XMLHttpRequest}

\section{Hasil dan Pembahasan}

Pencarian content portal berita akan diawali dengan memberikan kata kunci pada form. Sebagai contoh kata kunci yang dimasukan adalah "Jokowi" yang proses pencarian dilakukan pada tanggal 3 Juni 2018 dan 15 Juli 2018, ternyata diperoleh hasil yang berbeda, sesuai dengan trend berita yang sedang terjadi. Pada tanggal 3 Juni terdapat 5 berita pada 5 portal berita hanya ada 1 berita yang terkait dengan "Jokowi", sedangkan pada tanggal 15 Juli 2018 terdapat 19 berita pada 5 portal berita. Jika diperhatikan pada portal berita detik ada 2 berita, portal berita antara dan sindo masing-masing ada 1 berita, portal berita liputan 6 ada 5 berita dan portal berita metrotv ada 10 berita.

\begin{tabular}{|c|c|c|}
\hline Sumber & Judul & Link \\
\hline detik & $\begin{array}{l}\text { Gatot Cium Tangan } \\
\text { SBY, Gerindra: } \\
\text { Jokowi Juga Cium } \\
\text { Tangan Megawati } \\
\end{array}$ & $\begin{array}{l}\frac{\text { http://news.detik.com/read/2018/06/03 }}{\text { /202005/4051310/10/gatot-cium-tangan-sby- }} \\
\text { gerindra-jokowi-juga-cium-tangan-megawati }\end{array}$ \\
\hline antara & $\begin{array}{l}\text { PBNU dukung } \\
\text { Jokowi jika pilih Cak } \\
\text { Imin }\end{array}$ & $\begin{array}{l}\text { https://www.antaranews.com/berita/ } 715688 \\
\text { pbnu-dukung-iokowi-iika-pilih-cak-imin }\end{array}$ \\
\hline liputan6 & $\begin{array}{l}\text { Cak Imin: Sangat } \\
\text { Rugi Jokowi Tak } \\
\text { Bareng Saya }\end{array}$ & $\begin{array}{l}\text { https://www:liputan6.com/news/read/3547912 } \\
\text { /cak-imin-sangat-rugi-iokowi-tak-bareng-sava }\end{array}$ \\
\hline tribun & $\begin{array}{l}\text { Dewan Pakar Golkar } \\
\text { Dorong Kader } \\
\text { Internal Sebagai } \\
\text { Cawapres Jokowi }\end{array}$ & $\begin{array}{l}\text { http://www.tribunnews.com/nasional/2018/06 } \\
\text { /03/dewan-pakar-golkar-dorong-kader- } \\
\text { internal-sebagai-cawapres-iokowi }\end{array}$ \\
\hline metrotv & $\begin{array}{l}\text { Pemerintah Dituding } \\
\text { tak Beritikad Baik } \\
\text { soal Revisi UU } \\
\text { KUHP }\end{array}$ & $\begin{array}{l}\text { http://news.metrotvnews.com/hukum } \\
\text { /zNAwXYvk-pemerintah-dituding-tak- } \\
\text { beritikad-baik-soal-revisi-uu-kuhp }\end{array}$ \\
\hline
\end{tabular}

\begin{tabular}{|c|c|c|}
\hline Sumber & Judul & Link \\
\hline detik & $\begin{array}{l}\text { Saat Fahri Hamzah Tiru Gaya Jokowi } \\
\text { Bagi-bagi Sepeda }\end{array}$ & $\begin{array}{l}\text { https://news.detikcoom/read/2018/07/15/235904/4116251/10/saat- } \\
\text { fahri-hamzah-tiru-gaya-iokowi-bagi-bagi-sepeda }\end{array}$ \\
\hline detik & \begin{tabular}{|l} 
Pilihan Isi Saku Jokowi yang \\
Dinantikan SBY
\end{tabular} & \begin{tabular}{|l|} 
hittps://news.detikcom/read/2018/07/15/215802/4116168 \\
10 pilihan-isi-saku-iokowi-yang-dinantikan-sby
\end{tabular} \\
\hline antara & $\begin{array}{l}\text { Jokowi ajak masyarakat tonton film } \\
\text { "Sultan Agung", kolosal terbesar } \\
\text { Indonesia }\end{array}$ & $\begin{array}{l}\text { httpg://wnww.antaranews.com/berita } 726971 / \text { iokowi-ajak- } \\
\text { masyarakat-tonton-film-sultan-agung-kolosal-terbesar-indonesia }\end{array}$ \\
\hline sindo & $\begin{array}{l}\text { Kedua Poros Koalisi Pilpres Saling } \\
\text { Intip Calon yang Akan Diusung }\end{array}$ & $\begin{array}{l}\text { httpg://nasional.sindonews.com/read/1322018/12/kedua-poros- } \\
\text { koalisi-pilpres-saling-intip-calon-vang-akan-diusung-1531667319 }\end{array}$ \\
\hline liputan6 & $\begin{array}{l}\text { Jokowi Harap Studio Alam Hidupkan } \\
\text { Ekonomi Desa Gamplong }\end{array}$ & $\begin{array}{l}\text { hittps://wnuw.liputan6.com/news/read/3589871/10kowi-harap- } \\
\text { studio-alam-hidupkan-ekonomi-desa-gamplong }\end{array}$ \\
\hline liputan6 & $\begin{array}{l}\text { Menpora Janjikan Bonus Rumah Bagi } \\
\text { Atlet Peraih Emas Asian Games }\end{array}$ & $\begin{array}{l}\text { hittps://wuww liputan6.com/news/read } 3589136 \text { menpora-ianikan- } \\
\text { bonus-rumah-bagi-atlet-peraih-emas-asian-Eames }\end{array}$ \\
\hline liputan6 & $\begin{array}{l}\text { Jokowi Resmikan Pembangunan } \\
\text { Ponpes MTA di Karanganyar }\end{array}$ & $\begin{array}{l}\text { hitps://wwww.liputan6.com/news/read/3589865/iokowi-resmikan- } \\
\text { pembangunan-ponpes-mta-di-karanganyar }\end{array}$ \\
\hline liputan6 & $\begin{array}{l}\text { Jokowi Targetkan Venue Asian } \\
\text { Games di Palembang Rampung } 2 \\
\text { Minggu Lagi }\end{array}$ & $\begin{array}{l}\text { httpg://wwww.liputan6.com/regional/read } 3589119 \text { /iokowi- } \\
\text { targetkan-venue-asian-games-di-palembang-rampung-2-minggu- } \\
\text { lagi }\end{array}$ \\
\hline liputan6 & $\begin{array}{l}\text { PSI: Siapa pun Cawapres Jokowi } \\
\text { Kami Dukung } 100 \text { Persen }\end{array}$ & $\begin{array}{l}\text { hltpg://wwww.liputan6.com/newv/read/3589686/psi-siapa-pum- } \\
\text { cawapres-iokowi-kami-dukung-100-persen }\end{array}$ \\
\hline metrotv & $\begin{array}{l}\text { The Initiative Institute: Rommy } \\
\text { Paling Layak Dampingi Jokowi }\end{array}$ & $\begin{array}{l}\text { hittp//newvs.metrotvnews.com/politik/ 8NOVDQMk-the-initiative- } \\
\text { institute-rommy-paling-layak-dampingi-jokowi }\end{array}$ \\
\hline metrotv & $\begin{array}{l}\text { Cak Imin Masuk Daftar Jokowi, JOIN } \\
\text { Langsung Potong Tumpeng }\end{array}$ & 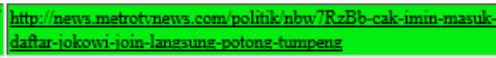 \\
\hline metrotv & $\begin{array}{l}\text { Alasan Cak Imin Masuk Kantong } \\
\text { Jokowi }\end{array}$ & 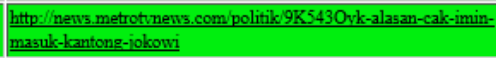 \\
\hline metrotv & $\begin{array}{l}\text { Salah Sebut Dusum, Warga Koreksi } \\
\text { Ucapan Jokowi }\end{array}$ & $\begin{array}{l}\text { hittp://iateng metrotvnews.com/peristiwa/RkiZO7Gk-salah-sebut- } \\
\text { duesm-warga-koreksi-ucapan-iokowi }\end{array}$ \\
\hline metrotv & $\begin{array}{l}\text { Jokowi Minta Warga Apresiasi } \\
\text { Sejarah }\end{array}$ & 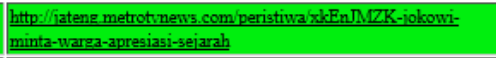 \\
\hline metrotv & $\begin{array}{l}\text { Jokowi Blusukan ke Pasar Gede } \\
\text { Klaten }\end{array}$ & $\begin{array}{l}\text { hlttp://video.metrotunews.com/plaw/2018/07/15/901834/iokowi- } \\
\text { blusukan-ke-pasar-gede-klaten }\end{array}$ \\
\hline
\end{tabular}

Gambar 10. Hasil Pencarian "Jokowi” Pada Portal Berita dengan Waktu yang Berbeda 


\section{Kesimpulan dan Saran}

Dalam penelitian ini telah berhasil dibuat sebuah aplikasi yang bertujuan untuk mencari content pada portal berita dengan teknik sindikasi berbasis ajax-soap web service. Uji coba yang dilakukan menunjukan aplikasi responsif menghasilkan tautan (link) terhadap trend pemberitaan yang ada pada masing-masing portal berita. Aplikasi ini dapat dikembangkan untuk analisa trend informasi atau deteksi distribusi pemberitaan yang tidak benar (hoax).

\section{Daftar Pustaka}

[1] Fawcett Joe, Liam R.E. dan Ayers, Quin Danny, 2012, Beginning XML, 978-1-118-16213-2, John Wiley \& Sons, Canada.

[2] Margianto, J. Heru dan Syaefullah Asep, 2014, Media Online : Pembaca, Laba dan Etika Problematika Praktik Jurnalisme Online di Indonesia, Divisi Penyiaran dan Media Baru AJI Indonesia, Indonesia.

[3] KOMINFO, Menkominfo: Baru 100 Portal Berita Online Terverifikasi, https://kominfo.go.id/content/detail/12345/menkominfo-baru-100-portal-berita-onlineterverifikasi/0/berita_satker diakses 5 Juli 2017.

[4] PUSDIKLAT BPS, Perbandingan SOAP dan REST sebagai Web Service, http://pusdiklat.bps.go.id/index.php?r=artikel/view\&id=206 diakses 5 Juli 2017.

[5] Sumedt Jitpukdebodin, 2013, Web Architecture - Mechanism and Threats, I-Secure, USA.

[6] Suteja, Bernard Renaldy dan Toba, Hapnes, 2017, Web Cerdas itu Web Semantik, Rekayasa dan Implementasi Praktis, 978-602-6581-10-5, Garudhawaca, Indonesia.

[7] W3School, XML RSS, https://www.w3schools.com/xml/xml_rss.asp diakses 1 Juli 2017. 